\title{
Sumane Bewawö Hasi Ritual: A symbolic act respecting the ancestors in South Nias Regency
}

\author{
Ritual Sumane Bewawö Hasi: Tindakan simbolik penghormatan \\ kepada leluhur di Kabupaten Nias Selatan
}

\author{
Potensi Juniarti Hia ${ }^{1}$, Firman Yamonaha Zega ${ }^{2}$ \\ ${ }^{1}$ Student of the Sociology of Religion Postgraduate Program, Faculty of Theology \\ Universitas Kristen Satya Wacana \\ Salatiga, 52-60, Central Java Province, Indonesia \\ ${ }^{2}$ Doctoral Student of Sociology of Religion, Faculty of Theology \\ Universitas Kristen Satya Wacana \\ Salatiga, 52-60, Central Java Province, Indonesia \\ E-mail of corresponding author: hia.pjuniarti@gmail.com
}

\begin{abstract}
Sumane bewawö hasi is one of the rituals in the funeral ceremony originating from the Nias Tribe that is engaged in by the people in öri To'ene, öri Mazinö, and öri Onolalu in South Nias. This study aimed to determine the symbolic meaning of each of the series of rituals to do with the giving of sumane bewawö hasi. This study used a qualitative descriptive research method and symbolic interaction theory. The data collection in this study consisted of interviews, observations, and documentation techniques. Furthermore, the data analysis used data reduction, data analysis, and drawing conclusions. The result of this research shows that sumane bewawö hasi is a symbolic act that specifically aims to pay homage to the parents or ancestors as a symbol of separation. It can also involve famolakhömi ya'ira sofulo (glory/dignity of the community) and appreciation of the people attending the funeral. This ritual also aims to strengthen the kinship in the family (fahasara dödö si fatifusö) as a form of togetherness, celebrating the involvement of the entire extended family in the implementation of the religious and familial events. The implementation process consists of several stages: orahua sifatalifusö, fame'e sumane and the implementation of hölihöli Sumane.
\end{abstract}

Keywords: ritual; symbolic interaction; sumane bewawö hasi; ancestral respect; South Nias

\section{Abstrak}

Sumane bewawö hasi merupakan salah satu ritual dalam upacara pemakaman suku Nias yang dilakukan oleh masyarakat di öri To'ene, öri Mazinö, dan öri Onolalu di Nias Selatan. Penelitian ini bertujuan untuk mengetahui makna simbolik dari setiap rangkaian ritual yang dilakukan dengan pemberian sumane bewawö hasi. Penelitian ini menggunakan metode penelitian deskriptif kualitatif dan teori interaksi simbolik. Pengumpulan data dalam penelitian ini terdiri dari wawancara, observasi, dan teknik dokumentasi. Selanjutnya analisis data menggunakan reduksi data, analisis data, dan penarikan kesimpulan. Hasil penelitian menunjukkan bahwa sumane bewawö hasi merupakan tindakan simbolik yang secara khusus bertujuan untuk memberi penghormatan kepada orang tua atau leluhur sebagai simbol perpisahan. Ini juga bisa melibatkan famolakhömi ya’ira sofulo (kebanggaan/martabat komunitas) dan apresiasi orang-orang yang menghadiri pemakaman. Ritual ini juga bertujuan untuk mempererat tali persaudaraan dalam keluarga (fahasara dödö si fatifusö) sebagai bentuk kebersamaan, merayakan keterlibatan seluruh keluarga besar dalam penyelenggaraan acara keagamaan dan kekeluargaan. Proses implementasi terdiri dari beberapa tahapan yaitu orahua sifatalifusö, fame'e sumane dan implementasi hölihöli Sumane.

Kata Kunci: ritual; tindakan simbolik; sumane bewawö hasi; penghormatan leluhur; Nias Selatan

\section{Introduction}

The fact that Indonesia is a multicultural country is indisputable. This can be seen from the diverse and extensive socio-cultural wealth and geographical conditions. Indonesia has tens of thousands of large and small islands, and a population of hundreds of millions of people consisting of various ethnic groups and languages. Besides, the Indonesian population adheres to various religions and beliefs, such as Islam, Catholicism, Christianity, Hinduism, Buddhism, Confucianism, and other religious sects. The plurality of the Indonesian people is evident in the diversity of their ethnicities, cultures, and languages. The ethnic and cultural diversity of Indonesia cannot be separated from the cult touch of respecting the ancestors. The cult touch generates different practices of respecting ancestors in every culture and place in Indonesia.

Ritual is an activity that is always strongly related to religion. This activity then becomes a tradition in the practice of religious life. In religious rituals, humans symbolically try to develop and establish communication using divines (transcendent) powers, such as ancestral spirits, spirits, gods, God, or other magical forces that are considered and believed to be divine (transcendent). In religious rites or 
ceremonies, some actions can be seen, such as praying, kneeling, serving, sacrificing, eating together, dancing and singing, processing, performing arts, fasting, meditating, and contemplating, so that it can be understood that religious rites are worship activities manifested in symbolic expressions through language, movement, and religious thinking, which then becomes a sacred dimension and is lived continuously in religious life itself (Raodah 2015).

Rituals of respect for ancestors are still being practiced by a number of regions in Indonesia, although in its development, these rituals of respect for ancestors have shifted in meaning adapted to the context of the community. Mangongkal holi is one of the famous traditional rituals in Tanah Batak and also North Sumatera. Mangongkal holi is a ritual carried out by the Batak Toba community as a form of expression of respect from the Batak Toba community for their ancestors, which is carried out by digging back the bones of their ancestors (Warneck 2001) who have died after a few years ago and moving them to a new tomb, which is better than before and followed by traditional events and parties (Prayitno 2020). The mangongkal holi ritual is almost similar to the rambu solo ritual in Toraja, South Sulawesi, because it is related to funeral rituals and respect for ancestral spirits and the dead people followed by a big feast and also eating together. Rambu solo is a traditional funeral ceremony and is sacred, and is closely related to the Torajan philosophy of Puya or heaven (Ismail 2019). This ritual aims to respect and deliver the spirits of people who have died to the spiritual realm, and as a form of worshiping the spirits of ancestors and predecessors by slaughtering buffalo as sacrificial animals (Putri 2020). The Hindu community in Bali also has a tradition of worshiping ancestral spirits with the aim of maintaining good relations between people who are still alive and the spirit world, through the media of worship or menhir, including terraces, which are pyramid-shaped buildings as a medium of worship to respected figures, or they are believed as a link between the living and the dead (Rema 2014). The worship for ancestors in Balinese society is enshrined and confirmed through written media in palm leaves or tal which they call historical texts (babad) or steles (prasasti) (Covarrubias 2013).

Based on all the practices of respecting the ancestors above, it can be seen that living humans still certain and believe that their ancestors also affect natural life in the world. Therefore, ancestors are respected in distinct forms and practices of respect according to particular ethnicities and cultures. Sumane bewawö hasi is one of the ritual traditions of the Niha Raya (South Nias) people, particularly in öri To'ene, öri Mazinö, and öri Onolalu as a form of respect for their ancestors. Sumane bewawö hasi means an offering made on a coffin in a funeral ceremony. This ritual is an ancient tradition inherited from the ancestors of the Niha Raya people which is still being practiced today as a form of local community belief.

The ritual of giving of sumane bewawö hasi is one of the rituals of respect for ancestors of the people of South Nias which has survived and is unique. This ritual is unique because the people of South Nias do not generally practice it and it is only practiced in three öri (regions) in South Nias. Moreover, the implementation process is also different from the worship/respect of ancestors in some regions in Indonesia. This ritual is carried out by giving a sumane (offering) in the form of ana'a (gold) on the coffin. Besides, the topic of sumane bewawö hasi has never been studied specifically and in-depth in previous studies relating to themes of culture, customs, religion, and local wisdom in Nias society. Thereby, this study tried to critically and deeply analyze the activities or symbolic actions carried out by the people in öri To'ene, öri Mazinö, and öri Onolalu which express respect for ancestors through the giving of sumane bewawö hasi which is carried out at the death/funeral ceremony.

Meanwhile, to develop an analysis on the theme of sumane bewawö hasi, this study used the symbolic action theory by George Herbert Mead and Jeffrey C. Alexander. Mead and Alexander based this symbolic interaction theory on cultic practices in existing rituals in the community. Symbolic action is an approach at the micro level that focuses on individual interaction patterns, by understanding social life which is formed through the process of interaction and communication between individuals (self) and between groups using symbols that are understood collectively in various interactions between social actors (Mead 1934). In symbolic interactions, humans are assumed to be creatures who act on the basis of how they define, interpret, and conceptualize things based on their experiences (Jones 2010). The reciprocal interaction of these actors then produces a community order based on the meaning of the existing symbols, so that social interactions that occur in the community are a form of cooperation between individuals and other individuals that become the focus of symbolic action orders at the micro and community at the macro scale (Elbadiansyah 2014).

Alexander saw the substance in the process of social interaction, not only in symbols and meanings, but also includes all actions in multidimensional human interactions. Ritual and culture socially consist of a meaning structure in terms of a set of signs by which society takes an action and lives in it. This is in accordance with what is illustrated by Parson that culture is the main power that binds the system of action (Goodman 2004). However, Alexander emphasized that it is also necessary to see that culture 
is not only a matter of meaning which contains a system of symbols, but the articulation of a culture is found through its social actions. Therefore, in his theory, Alexander acknowledged the process of a ritual not only focusing on the meaning of a performance, but also on symbolic actions, cultural texts, and the actors in the performance.

\section{Research Methods}

The study on this topic was descriptive by using qualitative research methods to examine and reveal the meaning of an object in its context (Yusuf 2004), and at the same time to explore and understand the meaning that is considered to come from social or human problems by a number of individuals or groups of people (Creswell 2016). This study was conducted in South Nias Regency using several data collection techniques. First, interviews were conducted through personal and group interviews. In this study, the interviews were conducted with a number of traditional leaders in öri To'ene, öri Mazinö, and öri Onolalu, interviews with church leaders, and interviews with the community as the ritual actors in the three öri. Second, observation. The observations made were in-depth observations directly into the field to observe the behavior or activities of individuals at the research locations located in three öri in South Nias. Third, literature study. In this study, the authors conducted a literature study to obtain a theoretical foundation through books, literature, or some notes related to the research carried out. Fourth, qualitative audio and visual material in the form of photos, videos, art objects, or all kinds of voices and sounds related to this study (Creswell 2016).

The data analysis technique used included 3 components; first, data reduction. Data reduction means categorizing, selecting important things, and eliminating unnecessary data. Second, data display. After reducing the data, the data obtained were presented in the form of a brief description. Third, conclusion. The conclusions were drawn from the results of data analysis and this was the final component of data analysis techniques (Sugiyono 2013).

\section{Results and Discussion}

\section{Sumane in the culture of the Nias people}

Ono Niha (Nias people) understand sumane as a tradition passed down from their ancestors and has been practiced over generations by all Nias people to this day. As a tradition of the ancestors, informant MDH (an aristocrat/Si'ulu in öri To'ene) and informant FZM (an aristocrat/Si'ulu in öri Mazinö) said that the early history of the emergence of the sumane ritual could not be clearly ascertained. However, the Nias people in the general public and the Niha Raya people in particular believe that the sumane tradition is a legacy of ancestors that existed long before the Gospel entered Nias Island. Sumane has become an inseparable part of the life of the Nias people. This is because sumane has bound, covered, and colored all aspects of the life of the Nias people. For the Nias people in general and for the South Nias people in particular, the giving of sumane is a very important tradition and has a very high value in the implementation of all customary and religious activities.

Sumane is a form of respect or appreciation made and provided by the Nias people to other people, or more precisely, sumane is a means for the Nias people to treat other people in an authoritative and dignified manner. As stated by informant HDH (Si'ulu in öri To'ene), understanding of the people of sumane is always related to two things, the first: fangandrö howu-howu (asking for blessings), and the second: lakhömi (glory, self-respect, dignity, and honor). The more a person is considered molakhömi (respectable and dignified), the more lafosumange (respected/considered honorable and dignified) they are. This indicates that the people who receive sumane are people who are highly valued, appreciated, and respected, for example: matua (parents-in-law), sibaya (uncle's party), talifusö (siblings), and also people who come visiting the house, such as government officials, church servants, and also customary leaders who are not related by blood with the family. This was confirmed by an informant FHR (Si'ulu in öri Onolalu) who stated that the giving of sumane covers the whole life of the community starting from rituals or traditional ceremonies, religious ceremonies, and activities in government. This shows that every phase or stage of life in the Nias community is generally related to sumane, starting from birth (fa'atumbu), marriage (fä̈li or mowatö), to death (fa'amate). Giving sumane also includes other social-cultural events, such as famatörö töi fa' asi'ulu (giving a nobility title known as si'ulu), fatomosa (house building), and so on.

One of the cultures of giving sumane that is most often practiced by the Nias people is sumane in the form of the greeting "Ya'ahowu", which is broadly known as a typical greeting for the Nias people. Another example of giving sumane can also be seen in some rituals in the Nias community. First: fangowai and fame'e afo, which are sumane in marriage ceremonies (Maru'ao 2014). Second: famaolagö simbi 
mbawi (pork jaw serving) or it is known as famaolagö telau mbawi in some areas of South Nias (Lase 2017). This action is understood as a form or manifestation of giving sumane to the tome (guest), which is carried out through a banquet of pork dish with simbi/telau mbawi. Third: sumane in the ritual of birth. Sumane in the birth rite is carried out when a child was born into a family. The parents of the child are obliged to ask for a blessing (howu-howu) from the sibaya (uncle) by bringing sumane in the form of goods, which is gold (ana'a), and providing sumane ni' $a$ (food) in the form of pork and rice (Wiradnyana 2010). RDH, one of the informants said that the interesting part in giving sumane to this rite is that at the birth of the next child (second, third, and so on) in the same family, fangandrö howuhowu is no longer practiced, except when the sex of the next child is different from the sex of the first child. The whole series of giving sumane that is carried out in the life rites of Ono Niha aims to ask for blessings (howu-howu) from people who are considered valued and can give blessings. The blessing requested can be in the form of; blessings for health, success, offspring, protection from bad things, etc. Besides, the Nias people also acknowledge sumane not only in the scope of culture or customs. Sumane is also practiced in the religious sphere as a form of gratitude for the blessings they have received, for example: giving sumane to church servants, which is usually specifically addressed to pastors or priests, church teachers, church leaders, and so on.

\section{Sumane Bewawö Hasi Ritual: Respect for ancestors}

The Nias people (Ono Niha) are people who live in a megalithic culture. Megalithic culture is strongly related to respect for ancestors. For Ono Niha, parents are a real manifestation of gods (ama, Lowalangi ba gulidanö), who can provide protection, blessings, and also curses. Therefore, Ono Niha worships parents as gods and obeys their every command (amakhoita zatua). Respect for parents continues even after death. Ono Niha made $a d u$ (statue) to commemorate and honor their parents or ancestors, so that with the presence of adu zatua, the spirits of the ancestors would always be with them and listen to the requests of their descendants. Adu zatua is an 'image or statue of an ancestor' that is believed to be an intermediary for connecting with gods, spirits, and ancestors (Lömbu 2019). Through adu, Ono Niha hopes for material blessings or rescue from disasters and also healing from illnesses (Hummel 2015).

Giving sumane bewawö hasi is a tradition in the funeral ritual which is carried out by the South Nias people repeatedly and is believed to be a form of respect for their ancestors. Referring to the definition of ritual by Turner, it is emphasized that rituals are always based on religious beliefs, both in authority and on mystical powers (Winangun 1990). Moreover, Edward Shill, as quoted by Bell, clarifies the relationship between ritual and culture: according to him, the two are intertwined but can be separated, in which beliefs could exist without rituals; rituals, however, could not exist without beliefs (Burkert 1983). Thereby, the tradition of giving sumane bewawö hasi is a ritual that is also based on the beliefs of the local community. This is evident from the statements delivered by customary leaders that the implementation of the ritual of giving sumane is carried out not only as a form of respect for the ancestors, but contains prayers and hopes for the blessings of the ancestors.

Giving sumane bewawö hasi is not only an act of respect for the parents who died/ancestors, but also has a much more crucial meaning than the only tradition. The community as actors of this ritual believes that giving sumane bewawö hasi can bring blessings and curses from the ancestors. The belief of Nias community in lowalangi ba gulidanö (visible God = parents), that are believed to be a source of blessings (sangehowu), is seen by the author as one of the major factors behind the emerge of an understanding of the blessings of the ancestors. Thus, it is not surprising that the Nias people have very high respect for their parents, both while they are alive and when they die. Respect for the ancestors ultimately leads to the worship of parents as gods. This is more obvious by the making of the adu zatua (ancestral statue) as a manifestation of the presence of the ancestors who can give blessings even as a source of hope for the family, and curses for those who do not carry out the mandate and respect their ancestors. Blessings and curses from ancestors are also believed by the Ndembu people, especially in disturbance rites. The Ndembu community, as explained by Turner, believes that the spirits of their ancestors will bring bad luck and disaster to families or communities that do not respect and neglect the mandate of their parents/ ancestors (Turner 1975). It is different from what has been stated by Durkheim about the warramunga ceremony, which is a ceremony of respecting the ancestors as a way to revitalize past memories in the minds of families or new generations of ancestors (Alexander 2006).

\section{Sumane Bewawö Hasi and encounter with Christianity}

The encounter between Christianity and culture is not a new issue. This has been happening since the beginning of Christianity and has continued over time to the present day. Tuhoni said that in the encounter between Christianity and the culture of the Nias people, missionaries established a different approach (Hummel 2015). This approach is a firm rejection of the entire series of old religious ceremonies and it is stated that these rites are "pagan" practices originating from the dark ages. The sacred things in 
Nias culture, including $a d u$ and ere, are even claimed to be symbols of evil. According to informant $\mathrm{ADH}$ (Si'ulu in öri To'ene), the giving of sumane has a very close relationship with the tribal religion of the Nias people, which is the worship of ancestral spirits or $A d u$. Furthermore, informant NBG explained that sumane bewawö hasi is a custom passed down by the ancestors of the Niha Raya (South Nias) people that existed long before the gospel entered Nias land, and is also an "amakhoita hada" (customary provision), which is a legacy from the ancestors of the Niha Raya people or it can also be considered as fondrakö substancesua föna (customary law that has been mutually agreed upon by the aristocracy and customary leaders).
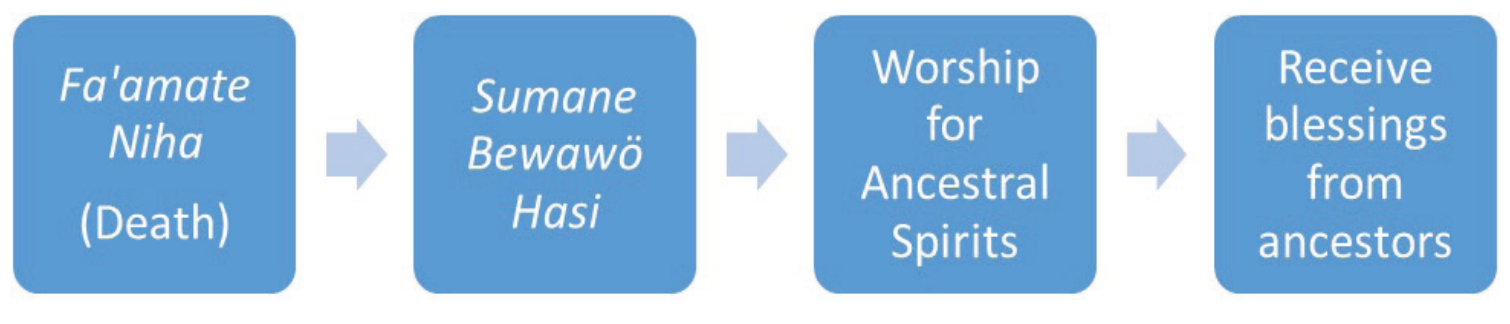

Figure 1.

The process of sumane bewawö hasi in pre-Christianity Source: Personal data

Based on this reality, as presented in Figure 1, it can be seen that the ritual of giving sumane was motivated by the beliefs and convictions of the South Nias people in the past on the importance of respect for parents, so that when parents or ancestors died, the spirits are believed to be still alive and can continue to bless, protect, and care for all their descendants. The belief in the blessings and curses of the ancestors has been adhered to by the local community before Christianity entered and was accepted by the community.

The chart above illustrates the understanding and the process of the ritual of giving sumane bewawö hasi before the entry of Christianity in Nias. The sumane bewawö hasi ritual in pre-Christian times, which is understood as worship for ancestors, is clearly rejected and considered a practice inconsistent with Christian teachings. However, based on the authors' findings regarding the ritual of giving sumane bewawö hasi, it appears that the rejection from the Christianity of the old religious rites has not been completely eliminated. This is due to the fact that religious rituals have been integrated and become a socio-cultural identity in the Niha Raya community. Thus, even though the indigenous people (Niha Raya) decide to become Christian, some cultural rituals are still maintained and continued to be practiced. As explained by Titaley (2021), in its development, Christianity has brought changes in the lives of indigenous peoples. Some elements in the old religious rites are eventually used by missionaries in introducing Christianity to the indigenous people.

As an old religious ritual, sumane bewawö hasi has obviously experienced rejection from Christianity, particularly by a number of churches in the South Nias area. As stated by Adrianus Duha, some churches in the South Nias region initially showed a reaction against the practice of giving sumane bewawö hasi because they were considered inconsistent with the teachings and foundations of the Christian faith, including: GKII (Gereja Kemenangan Iman Indonesia) dan Bala Keselamatan. In the end, even though some churches rejected this, it was unable to hinder or stem the practice of carrying out the ritual of giving sumane bewawö hasi. GKII not only rejected the implementation of the ritual of giving sumane bewawö hasi, but also rejected the slaughter of pork as a symbol of respect for the Nias people in all traditional ceremonies, especially in funeral ceremonies. The attitude of the church actually triggered a strong reaction from the community, and some churches were almost expelled because they were considered trying to remove the customs and values of the ritual of giving sumane. "Matema' somuso dödö ni'ohemö, ba hiza'i böi tibo'ö hada zi no lafalua ira amama" means "the gospel message brought by the missionaries is accepted, but that does not mean that the customs and culture inherited from the ancestors are eliminated by the presence of religion", is a statement from the community who think the provisions of the church are not the proper solution in introducing Christianity to the indigenous people. Turner also noticed the same thing that every ritual that exists in the community is not only a belief but deeper than that, ritual should be a forum for the community to express and obey existing cultural values (Turner 1969).

The presence of Christianity on the Nias Island and that it is accepted by the Niha Raya people brought changes in the value and form of the sumane bewawö hasi ritual. The church has started to make some changes or shifts in the stages of carrying out the ritual of giving sumane bewawö hasi which is 
considered opposite to Christian values. The ritual of giving sumane is no longer placed right on the coffin, but the sumane is placed in a container of a box made of cardboard or wood that is put next to the coffin. Besides the layout for giving sumane, the church has also shifted the order in which the ritual of giving sumane bewawö hasi is carried out. In pre-Christian times, the ritual of giving sumane bewawö hasi was the final stage at a funeral ceremony or shortly before the body was buried. Meanwhile, in post-Christianity (until now), the church combines it with other traditional events, which are carried out before the funeral services are done by church servants.

The values contained in the ritual of giving sumane bewawö hasi are gradually being rectified and interpreted in a Christian way by the church. Thus, the ritual of sumane bewawö hasi by the Niha Raya people is no longer interpreted as a ritual of worship or respect for ancestors as in the pre-Christian era. However, the ritual of sumane bewawö hasi is interpreted by the Niha Raya people as a form of respect for the family and community who are present (famolakhömi ya'ira sofulo) during the ritual. In addition, the prayers and hopes of the Niha Raya people in pre-Christian times for their ancestors are now completely directed at Jesus Christ, who is believed to be Lord and Savior. The implementation process of the sumane bewawö hasi ritual in öri To'ene, öri Mazinö, dan öri Onolalu communities in post-Christian times can be illustrated as follows in Figure 2:

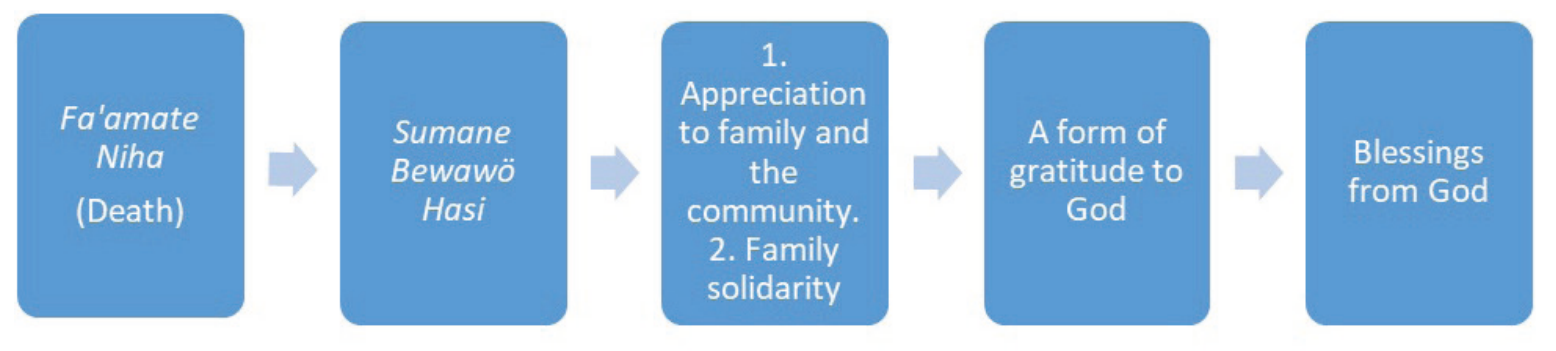

Figure 2.

The process of sumane bewawö hasi in post-Christianity Source: Personal data

\section{The implementation process of the Sumane Bewawö Hasi ritual}

Women are the only main actors in the ritual of giving sumane bewawö hasi. This is because the position of women in the Niha Raya community is considered higher and more valued than men, and they are seen as queens in the household. The status of women who are considered to be higher than men is proven from the habits of the South Nias people in the past, in which when men passed women, men were obliged to avoid them in two to three meters away and bow their heads as a sign of respect for these women. In the sumane bewawö hasi ritual, women who carry out the act of giving sumane are only married women who are from the line of the deceased person (in Nias language, it is called ono regerege), including: ono alawe (biological daughter), iwa si 'alawe (biological sister), and ono nakhi (niece of the sister).

The implementation process or procedure of the sumane bewawö hasi ritual has three stages, consisting of, first, orahua sifatalifusö (family association/affiliation). The ritual of giving sumane will be preceded by orahua sifatalifusö led by si'ulu and or si'ila. According to informant NBG (Si'ulu in öri Onolalu), this stage aims to explain the obligations to the family by the ritual actor that must be fulfilled based on rege-rege (closeness) with the deceased. Second, fame'e sumane bewawö hasi. The fame'e sumane bewawö hasi stage is held after the orahua sifatalifusö has finished. This stage will be led by si'ulu or balö si'ulu from the family of the deceased, and is carried out based on the order of closeness (rege-rege) and the age of the sumane giver. The order of the ritual of giving sumane bewawö hasi as revealed by informant MDH is started by ono alawe (biological daughter), then followed by talifusö alawe or iwa si'alawe (biological sister) of the deceased, followed by ono nakhi (niece) and all other family members of the female lineage.

The form of sumane is usually in the form of ana'a (gold) and is generally in the form of a necklace or bracelet. The measure of the sumane given is determined by the rege-rege or closeness to the deceased. For example: (1) for ono alawe (biological child) group, the sumane given should not be less than 3-12 gold stones (pau) with a minimum of 16 carats; (2) for iwa si'alawe (biological sister), it is also must not be less than 2-3 gold stones (pau), and must not exceed the sumane of ono alawe, unless the ono alawe of the deceased is unmarried or does not have a daughter, then it is obligatory for the iwa si'alawe to give sumane with a weight of 3 gold stones (pau); (3) for ono nakhi group, it is 1 stone gold (pau). However, in some areas, according to informant ADH, the sumane that is given can also be in the form 
of weapons of war, such as: tolögu (a sword with a sheath wrapped in gold and its hilt is decorated with tiger/crocodile teeth; this is especially for aristocrats), and balatu töla zaga (keris with a sheath wrapped in gold). Besides being valuable objects in the Nias Selatan community, these objects are also seen as symbols of a person's identity. In the technical implementation, HDH said that giving sumane is carried out by lifting the sumane and simultaneously showing it to the family (wife or mother), and to all the people present, before the sumane is placed in a box that has been prepared on top of the coffin.

Third, hölihöli sumane. The interviewees who are customary leaders and also ritual actors stated: hölihöli sumane is an event that is carried out a few days after the ritual of giving sumane and also a funeral ceremony, or more precisely, it is carried out together with a fanasi event (a service of gratitude for the completion of the construction of the grave). In the fanasi event, all the extended families will gather together, and the bereaved families will in particular give the opportunity to the ono alawe, iwa si'alawe, and ono nakhi to carry out redemption (hölihöli) for the sumane that has been placed in the coffin at the funeral. The sumane given in the form of gold will be redeemed (lahöli) with bawi (pork) and fakhe (rice). However, later in its developments (including today), the sumane can be redeemed not only for pork and rice, but also for an amount of money that has been put in an envelope.

The sumane bewawö hasi ritual is generally carried out in the same stages, both to ordinary people and to people with the status of the aristocrat of "si'ulu and si'la". However, there is a very prominent or significant difference between that of the aristocrats and the common people at the funerals. The death ceremony of a si'ulu will be la'owasaini (celebrated) for a week or even a month. Some of the activities that will be carried out in these traditional ceremonies include: famözi göndra (playing traditional musical instruments), lafatörö ba newali (lifted up and paraded around in its territory), molaya niha (dancing by jumping), and molau hoho (humming/singing a poem or verse). During the traditional ceremony, the si'ulu body will continue to be protected and guarded by four si'ila people. Meanwhile, when si'ila died, they will only be lifted up and paraded around half of their territory. Another difference that differs the death ceremony of aristocrats and common people is the number of pigs slaughtered at the funeral ceremony, in which the number of pigs slaughtered at the funeral ceremony for si'ulu and si'ila is more than that for the general public.

\section{Sumane Bewawö hasi as a symbolic action}

Ritual is inseparable from social life. Rituals are routines carried out to maintain and preserve the cultural values passed on by the ancestors. The main supporters of ritual performance are traditions and symbols. In general, every symbol used in a ritual contains a special meaning or message in accordance with the existing context in the community. This is in line with Bell's thought, which emphasized that the context of ritual in the community is dynamic and continues to follow social change (Patty 2014). According to Alexander (Alexander 2006), changes in ritual occur radically, both internally and in relation to social structures and actions. Historical and theoretical shifts make ritual less like ancient rituals, but more like theater (performance). Social actors who act as leaders and actors of the ritual acknowledge it no longer as an obligation but more as an option. The rituals carried out in the community even only focus on meanings and symbols. For Alexander, the process of a ritual should not only focus on the meaning and symbol of the performance, but the ritual process has to do with symbolic actions, cultural texts, and also the actors involved in it. Based on Alexander's understanding, it can be concluded that every ritual performed by the community is not only a matter of meaning and symbolic systems, but is furthermore a personification of collective actions that are practiced in the many rituals performed.

Based on in-depth observations of the ritual of giving sumane bewawö hasi, it can be seen that this ritual has undergone a shift in meaning, both in terms of substance and implementation. This is in accordance with the statements of the customary leaders of the three öri who explained that the meaning of the sumane bewawö hasi ritual is no longer understood as a ritual of worship and service for ancestral spirits, predecessor souls, or the spirits of the deceased; rather, it is an act of symbolic respect for the deceased and an expression of appreciation to the bereaved family and the community who are present at the funeral event (ceremony). Sumane, which was initially only in the form of gold, also underwent changes, in which: gold is no longer considered and designated as the only sumane in this ritual, but money is also allowed and accepted as a new form of sumane in the implementation of the sumane bewawö hasi ritual.

Communication and the exchange of symbols are elements of symbolic action. Symbols are used to understand the lives of the community through the process of interaction and communication between individuals and groups (Soeprapto 2002). Thus, it can be concluded that meanings and symbols are the impacts of human action and interaction, even symbols become a means or tool of being able to recognize the Holy and transcendent (Sitinjak 2018). Even more, human experiences and expressions are always illustrated through symbols and can indeed create the symbols themselves. Humans can respond 
to hierophanies through symbols, not only producing a reflection or an image of what is seen and heard but connecting it to the transcendent that is believed to be the power that creates these manifestations. Thereby, something that is originally profane in the symbol turns into something sacred. Based on this matter, the authors understand symbolic action as an activity carried out by humans by using symbols as a tool to connect to the transcendent, so that they existentially involve themselves to enter the root of everything that is considered the ultimate or highest reality.

In the ritual of giving sumane bewawö hasi, profane parents and ancestors become something sacred when the symbols used by the Niha Raya community in expressing respect are interpreted specifically and sacredly as a source of blessing and a source of life; so that, at the same time, the parents and ancestors become something that is believed to be sacred. The fact that parents and ancestors in the Nias community are manifestations of the sacred causes them to be respected and honored like gods. Respect and glorification for parents and ancestors are manifested through the worship of adu zatua and giving sumane bewawö hasi. It is in line with Durkheim's (Durkheim 2011) thoughts that what is profane is an event that usually occurs in the community in their daily lives that does not have spiritual values that are sacred; and this is what the people of South Nias carry out through the ritual of giving sumane bewawö hasi. The funeral ceremony will be sacred if it contains religious elements that connect it with ancestral spirits, in which there are moral values that bind the Niha Raya with the spirits of their ancestors.

Symbolic interaction is an activity that is characteristic of humans, that is communication or exchange of symbols that are given meaning by the community. Symbolic interaction focuses on the ways in which humans form or produce meaning, and how a symbol can be understood through interaction in a conversation. The meaning given to others, for example, situations, objects, and even oneself, can determine the behavior of the community. The ritual of giving sumane bewawö hasi is a form of culture that exists in the Niha Raya community which is full of symbols. Thus, based on the above reality, the authors conclude that the ritual of giving sumane bewawö hasi is a symbolic action in the cultural system of the Niha Raya community, particularly in öri To’ene, öri Mazinö, and öri Onolalu.

Gold as a form of sumane that is given by the family (ono alawe, iwa si'alawe, and ono nakhi) on the coffin is a symbol that indicates the closeness of the sumane giver with the deceased and with the nuclear family. This is proven by the existence of hölihöli (redemption) on the sumane. Besides, the process of giving sumane is openly presented and shown to the customary leaders and the entire community who are present at the ceremony. "Sambua kundi sumane, otu hölihöli" is an ancient ancestor's term which explains that sumane in the form of gold will be returned when the sumane giver brings hölihöli (redemption) in the form of money, pork, or other crops in accordance with the fatöfatö (provisions) which agreed. The process of performing hölihöli (redemption) of the sumane is carried out by the extended family one to three days after the funeral ceremony.

Sumane bewawö hasi as a symbolic action is also seen from the target use of the sumane. Sumane that has been redeemed with money, rice, pork, or other crops, will be used to cover costs, and necessities in customary events, including before the funeral, at the funeral ceremonies, and even customary events after the funeral/burial. There are some important events that are usually carried out before and after the funeral, including: famatunö halöwo (the moment when close family members gather to discuss plans for activities to be carried out at the funeral before being delivered or announced to the general public), fogao tanö (burial excavation work); fanawi mbambatö ba mbanua bö'ö (sending someone to inform the whole family everywhere about the time of the funeral); folau gawu ba lewatö (filling in the sand at the center of the grave, this filling of sand is also an expression of respect for the deceased); fanasi; faluaya mboni which is an activity of giving sumane to honored guests, si'ulu/aristocratic groups, and to those who carry out hoho (the spokesperson of the history or the life journey of the deceased), Sane'esi (people humming the lamentations), and sojago (people who every night protect the deceased bodies before being buried), in which this is carried out every night until the last night before the funeral ceremony. Sumane given by the bereaved family offers one or several pigs).

Another thing that needs to be emphasized regarding sumane bewawö hasi is that this ritual is closely related to the dignity of the bereaved family. The more who give sumane and the higher the value of sumane that is given, the dignity of the deceased and the dignity of the bereaved family will be higher in the eyes of the general public. In the sumane bewawö hasi ritual, the fahasara dödö si fatalifusö dimension is very highlighted, which is the value of solidarity and solidity of kinship or brotherhood in supporting the entire series of events during mourning events (funeral ceremonies).

Besides, the sumane bewawö hasi ritual is also interpreted as afuria falakhisa (the moment of the last meeting) between the deceased and the sumane givers which is considered as part of the ritual in relation to control and personal factors (Aksoz-Efe et al. 2018). Afuria falakhisa in the Niha Raya community 
is understood as a tribute from the living to the dead, which is witnessed by many people. In other words, it can be considered as a symbol or attribute of separation from the family to the deceased. This means that the giving of sumane is a form of respect, a sense of belonging, and a sign of the severity of separation from the deceased. On the other side, sumane bewawö hasi is a symbol of close relations with the deceased which is also shown to the general public or community at large; and as a means to stick brotherly relations in the extended family. This means that the ritual of giving sumane can be evidence that the sumane giver has a good relationship with the family, also to explain to the public that the deceased has a good personality in establishing a harmonious relationship with the family.

\section{Conclusions}

The ritual of giving of sumane bewawö hasi in the people in öri To'ene, öri Mazinö, and öri Onolalu is still currently practiced. This shows that the Niha Raya people have love and respect for their ancestral heritage. As a ritual passed on by the ancestors, sumane bewawö hasi is an obligation for the whole community to carry it out. Moreover, this ritual also follows developments in the community. This development is not meant to eliminate the meaning and existence of this ritual, but rather to maintain the ritual of sumane bewawö hasi with a more positive and constructive meaning and a better implementation system. In the implementation process of the ritual of giving sumane bewawö hasi, worship or service to the ancestor spirits and the predecessor souls is no longer the peak of this ritual, but as a symbolic action carried out to pay homage to the deceased, respect family and the community, and to strengthen family relationships. Today, the sumane bewawö hasi ritual places more worship and service to God as the peak of the whole series of events of giving sumane bewawö hasi, and as a means to ask God for blessings and help. This symbolic action helps the South Nias people to give a new meaning in the ritual of giving sumane bewawö hasi in accordance with the Christian teachings that have been adopted by the local community.

The ritual of giving sumane bewawö hasi which is practiced and lived by Niha Raya has become a tradition in the community that has been preserved over generations, which is adapted to the times and social changes in people's lives without destroying the cultural values contained therein. The dynamics of the times and social changes continue without losing the essential values in the ritual of giving sumane bewawö hasi in the life of the Niha Raya people, particularly in öri To'ene, öri Mazinö, and öri Onolalu.

\section{References}

Aksoz-Efe I, Erdur-Baker O \& Servaty-Seib H (2018) Death rituals, religious beliefs, and grief of Turkish women. Death Studies 42 (9):579-592.

Alexander JC (2006) Social Performance: Symbolic Action, Cultural Pragmatics, and Ritual. Cambridge: University Press.

Burkert W (1983) Homo Necans: The Anthropology of Ancient Greek Sacrificial Ritual and Myth. Berkeley: University of California Press.

Covarrubias M (2013) Pulau Bali: Temuan yang Menakjubkan. Denpasar: Udayana University Press.

Creswell JW (2016) Reseacrh Design: Pendekatan Metode Kualitatif, Kuantitatif, dan Campuran. Yogyakarta: Pustaka Pelajar.

Durkheim E (2011) The Elementary Forms of the Religious Life. Yogyakarta: IRCiSoD.

Elbadiansyah U (2014) Interaksionisme Simbolik dari Era Klasik hingga Modern. Jakarta: Rajawali Press.

Goodman GR (2004) Teori Sosiologi Modern. Jakarta: Kencana.

Hummel TT (2015) Salib dan Adu: Studi Sejarah dan Sosial-Budaya tentang Perjumaan Kekristenan dan Kebudayaan Asli di Nias dan Pulau-pulau Batu, Indonesia (1865-1965). Jakarta: BPK-Gunung Mulia.

Ismail R (2019) Ritual kematian dalam agama asli Toraja "Aluk To Dolo" (studi atas upacara kematian Rambu Solok). RELIGI: Jurnal Study Agama-Agama 15 (1):1-20.

Jones P (2010) Pengantar Teori-Teori Sosial: Dari Fungsionalisme hingga Post-Modernisme. Jakarta: Yayasan Pustaka Obor Indonesia.

Lase A (2017) Kabar Nias. [Accesed 10 February 2021]. https://kabarnias.com/budaya/adat-istiadat/ simbi-tanda-penghormatan-tulus-orang-nias-8523.

Lömbu CS (2019) Ruang ketiga dalam identitas baru Nias Padang Kristen. Thesis, Universitas Kristen Satya Wacana, Salatiga.

Maru'ao N (2014) Analisis penyebab menurunnya penerapan Fangowai Dan Fame'e Afo dalam pesta adat perkawinan di Kecamatan Lotu Kabupaten Nias Utara: Kajian sosiolinguistik. Thesis, Universitas Muslim Nusantara Al Washliyah, Medan. 
Mead GH (1934). Mind, Self, and Society: From the Standpoint of a Social Behaviorist. London: The University Of Chicago Press.

Patty FN (2014) Memahami teori ritual Catherine Bell dan fungsinya bagi studi teologi (Hermeneutis). Gema Teologi 38 (2):225-236.

Prayitno FO (2020) The development of the Mangongkal Holi Batak Toba indigenous ritual in Christianity in the Batak land. Anthropos: Jurnal Antropologi Sosial dan Budaya 6 (1):84-92.

Putri AS (2020) Makna upacara adat pemakaman Rambu Solo' di Tana Toraja. Jurnal Kreasi Seni dan Budaya 3 (1):72-81.

Raodah (2015) Simbolical meaning of Mappaoli Banua tradition in Banua Kaiyang Mosso society of West Sulawesi. Patanjala 7 (3):365-380.

Rema N (2014) Tradisi pemujaan leluhur pada masyarakat Hindu di Bali. Forum Arkeologi 27 (1):1-12.

Sitinjak PT (2018) Mangongkal Holi sebagai tindakan simbolik kekerabatan Batak Kristen Diaspora. Thesis, Universitas Kristen Satya Wacana, Salatiga.

Soeprapto R (2002) Interasionisme Simbolik: Perspektif Sosiologi Modern. Malang: Averroes Press.

Sugiyono (2013) Metode Penelitian Kuantitatif, Kualitatif dan R\&D. Bandung: Alfabeta.

Titaley YP (2021) Ancestors worship based on timorese perspectives in Oelbubuk Village, Central Mollo Sub-District, Timor Tengah Selatan District. International Journal of Entrepreneurship and Business Development 4 (1):1-6.

Turner V (1969) The Ritual Process: Structure and Anti-Structure. New York: Cornel University Press.

Turner V (1975) Revelation and Divination in Ndembu Ritual: Symbol, Myth, and Ritual. London: Cornell University Press.

Warneck J (2001) Kamus Batak Toba-Indonesia. Medan: Bina Media.

Winangun YW (1990) Masyarakat Bebas Struktur: Liminalitas dari Komunitas Menurut Victor Turner. Yogyakarta: Kanisius.

Wiradnyana K (2010) Legitimasi Kekuasaan Pada Budaya Nias: Panduan Penelitian Akeologi dan Antropologi. Jakarta: Obor.

Yusuf AM (2004) Metode Penelitian: Kuantitatif, Kualitatif dan Penelitian Gabungan. Jakarta: Kencana. 